УДК 347.41

DOI https://doi.org/10.32837/apdp.v0i86.2400

Б. В. Богдан

\title{
ЮРИДИЧНА ВІДПОВІДАЛЬНІСТЬ ЗА ПОРУШЕННЯ ЗАХОДІВ ЩОДО ЗАПОБІГАННЯ ІНФЕКЦІЙНИМ ХВОРОБАМ
}

Останнім часом епідеміологічна ситуація, яка склалась в Україні під впливом поширення інфекційної хвороби COVID-19, сприяла невідкладному реагуванню з боку держави загалом і уряду зокрема.

З уведенням урядом в Україні карантину, спрямованого на запобігання поширенню гострої респіраторної хвороби COVID-19, спричиненої коронавірусом SARS-CoV-2, актуальним стало питання про законодавче врегулювання юридичної відповідальності за порушення карантинних заходів, які спрямовані на запобігання інфекційним хворобам. У зв'язку із цим чинне законодавство України зазнало змін, які стосуються посилення юридичної відповідальності за порушення обмежувальних заходів та правил щодо карантину.

Окремі питання відповідальності за порушення заходів, спрямованих на запобігання інфекційним хворобам, були предметом дослідження у наукових публікаціях таких авторів, як О. Вдовичен, Ю. Лісової, С. Плахотнюк, А. Романюк, А. Сербін та інших. Проте запровадження змін щодо притягнення до юридичної відповідальності за порушення заходів щодо запобігання інфекційним хворобам потребує подальшого наукового аналізу.

Відповідно до ст. 1 Закону України «Про захист населення від інфекційних хвороб», карантин являє собою адміністративні і медико-санітарні заходи, які застосовуються для запобігання поширенню особливо небезпечних інфекційних хвороб [1]. «Обмежувальні протиепідемічні заходи» визначені даним Законом майже синонімічно терміну «карантин» - як медико-санітарні й адміністративні заходи, що здійснюються з метою запобігання поширенню інфекційної хвороби.

Наказом Міністерства охорони здоров'я України «Про внесення зміни до Переліку особливо небезпечних, небезпечних інфекційних та паразитарних хвороб людини і носійства збудників цих хвороб» гостра респіраторна хвороба COVID-19 віднесена до розділу «Особливо небезпечні інфекційні хвороби» [2]. У ст. 1 Закону України «Про захист населення від інфекційних хвороб» особливо небезпечними інфекційними хворобами визначено хвороби, для яких характерні важкі та/або стійкі розлади здоров’я, зафіксовані у значної кількості хворих. Особливо небезпечні хвороби вирізняються високим рівнем смертності та швидким поширенням серед населення.

Унаслідок унесення таких змін до Переліку особливо небезпечних, небезпечних інфекційних та паразитарних хвороб людини постановою Кабінету Міністрів України «Про запобігання поширенню на території України гострої респіраторної хвороби COVID-19, спричиненої коронавірусом SARS-CoV-2" із 12 березня 2020 р. на всій території України було встановлено карантин, термін якого постійно 
продовжувався через високу динаміку зареєстрованих випадків інфекційного захворювання COVID-19 [3].

Обмеження, які вводяться даним нормативно-правовим актом, мають тимчасовий характер і застосовуються саме в період установлення карантину.

Проте чинне законодавство визначає постійні обов'язки для осіб, які страждають на інфекційні хвороби або належать до бактерієносіїв: згідно зі ст. 19 «Про захист населення від інфекційних хвороб», до них належать обов'язки вживати заходів для запобігання поширенню інфекційних хвороб, які рекомендовані медичними працівниками; виконувати їхні вимоги і рекомендації щодо порядку й умов лікування; проходити необхідні медичні огляди й обстеження в установлені строки [1].

Для забезпечення належного дотримання населенням умов карантину законодавцем було посилено адміністративну та кримінальну відповідальність за порушення заходів запобігання інфекційним хворобам шляхом ухвалення Закону України «Про внесення змін до деяких законодавчих актів України, спрямованих на запобігання виникненню і поширенню коронавірусної хвороби (COVID-19)» [4]. Цим Законом передбачено внесення змін до Кодексу України про адміністративні правопорушення (далі - КУпАП) та Кримінального кодексу України (далі - ККУ).

Так, КУпАП було доповнено ст. $44^{3}$, якою передбачено накладення штрафу на громадян та посадових осіб за порушення правил щодо карантину людей, а також санітарно-гігієнічних, санітарно-протиепідемічних правил і норм, рішень органів місцевого самоврядування з питань боротьби з інфекційними хворобами. Санкція ст. $44^{3}$ КУпАП передбачає накладення на громадян штрафу в розмірі від 1000 до 2000 неоподатковуваних мінімумів громадян (від 17000 до 34000 тис. гривень), а також накладення штрафу на посадових осіб - від 2000 до 10000 неоподатковуваних мінімумів доходів громадян (від 34000 до 170000 тис. гривень) [5]. Адміністративні правопорушення, передбачені ст. $44^{3}$ КУпАП, розглядаються суддями районних, районних у місті, міських та міськрайонних судів (ст. 221 КУПАП).

Санітарно-гігієнічні та санітарно-протиепідемічні правила і норми, спрямовані на запобігання епідемічним та іншим інфекційним захворюванням і боротьбу з ними, встановлюються Законом України «Основи законодавства України про охорону здоров'я» [6], Законом України «Про забезпечення санітарного та епідемічного благополуччя населення» [7], Законом України «Про захист населення від інфекційних хвороб» [1]

Як зазначає М. Золотарьова, у ст. $44^{3}$ КУПАП описано сутність адміністративного правопорушення узагальнено, без конкретизації його змісту [8]. 3 даним твердженням не можна не погодитись, оскільки у ст. $44^{3}$ КУпАП чітко не визначено, що саме передбачає порушення правил щодо карантину, не закріплено конкретного припису чи вимоги.

Крім того, на наш погляд, ст. $44^{3}$ КУпАП дещо звужує суб'єктний склад осіб, яких може бути притягнуто до адміністративної відповідальності: застосування юридичної конструкції щодо визначення суб'єктного складу - «громадян» - ставить під сумнів, чи застосовуватиметься санкція даної статті до осіб без громадянства або іноземних громадян. Тому вважаємо за доцільне внесення змін до змісту ст. 44 КУпАП шляхом заміни слова «громадян» на словосполучення «фізичних 
осіб». Зауважимо також, що порушення санітарно-гігієнічних та санітарно-протиепідемічних правил і норм мають передбачати штрафні санкції диференційованого розміру, оскільки такі порушення мають різні наслідки для населення.

Так, у справі № 755/5547/20 Дніпровським районним судом м. Києва встановлено, що протокол про адміністративне правопорушення не відповідає вимогам ст. 256 КУпАП [9]. У даному судовому рішенні зазначається, що ст. $44^{3}$ КУпАП має бланкетний характер, тому у протоколі про адміністративне правопорушення має бути зазначено конкретний нормативно-правовий акт, який би встановлював відповідні правила щодо карантину людей, а також приписи яких саме правил не було дотримано особою. Проте, на думку суду, із протоколу про адміністративне правопорушення неможливо встановити, яким чином особою було порушено пп. 1 п. 2 постанови Кабінету Міністрів України «Про запобігання поширенню на території України гострої респіраторної хвороби COVID-19, спричиненої коронавірусом SARS-CoV-2», що унеможливлює перевірку наявності або відсутності в діях особи об’єктивної сторони адміністративного правопорушення.

Постановою Сарненського районного суду Рівненської області у справі № 572/873/20 також повернено матеріали начальнику Управління патрульної поліції про притягнення до адміністративної відповідальності фізичної особи-підприємця для належного оформлення [10].

Окремими постановами судів провадження у справі закрито через малозначність скоєного правопорушення. Наприклад, справа № 194/406/20, у якій Тернівський міський суд Дніпропетровської області закрив адміністративне провадження у справі, звільнив особу від адміністративної відповідальності у зв'язку 3 малозначністю адміністративного правопорушення, обмежився усним зауваженням [11]. Варто зазначити, що ст. $44^{3}$ КУпАП не передбачає такого виду санкції, як усне зауваження.

Натомість Єдиний державний реєстр судових рішень містить протилежні судові рішення, якими фізичних осіб притягнуто до адміністративної відповідальності у вигляді штрафу за порушення правил щодо карантину людей.

Так, постановою Бориспільського міськрайонного суду Київської області фізичну особу було притягнуто до адміністративної відповідальності за порушення правил щодо карантину людей, передбачених ст. $44^{3}$ КУпАП та постановою Кабінету Міністрів України «Про запобігання поширенню на території України гострої респіраторної хвороби COVID-19, спричиненої коронавірусом SARS-CoV-2", а саме здійснення перевезення понад 10 пасажирів водночас в автобусі, що виконував регулярне пасажирське перевезення на міському автобусному маршруті, та накладено адміністративне стягнення у вигляді штрафу в розмірі 17000 гривень [12].

Постановою Семенівського районного суду Чернігівської області у справі № 744/339/20 фізичну особу було притягнуто до адміністративної відповідальності у вигляді накладення штрафу за залишення межі карантину (самоізоляції), які були вказані в підписаній особою згоді на карантин (самоізоляцію) та проведення протиепідемічних і профілактичних заходів під час перетину державного кордону [13]. 
У ст. 325 ККУ визначено кримінальну відповідальність за порушення санітарних правил та норм щодо запобігання інфекційним хворобам, яка зумовлена спричиненням або можливим спричиненням поширення епідемічних, інфекційних та масових неінфекційних захворювань. Така відповідальність накладається у вигляді: 1) штрафу від 2000 до 5000 неоподатковуваних мінімумів доходів громадян (від 34000 до 85000 тис. гривень); 2) арешту на строк до шести місяців; 3) обмеження волі на строк до трьох років; 4) позбавлення волі на строк до трьох років [14].

Якщо таке порушення санітарних правил та норм щодо запобігання інфекційним хворобам спричинило загибель людей або інші тяжкі наслідки, то кримінальна відповідальність застосовується у вигляді позбавлення волі на строк від п'яти до восьми років [14].

Як слушно зазначає О. Вдовичен, порушення встановлених правил та норм повинно або мати причинний зв'язок із поширенням епідемій, інфекційних та масових неінфекційних захворювань на певній території України, або бути причинно пов'язаним зі створенням реальної загрози такого поширення [15].

Зазначимо, що ч. 1 ст. 325 ККУ під порушенням санітарних правил та норм щодо запобігання інфекційним хворобам визначає «дії, тобто активну поведінку суб’єктів, тоді як ч. 2 ст. 325 ККУ закріплює «діяння», що передбачають як дії, так і бездіяльність, тобто пасивну поведінку осіб (не вжиття відповідних заходів для запобігання інфекційним хворобам.

Підсумовуючи вищевикладене, можна зазначити таке.

Юридична відповідальність, передбачена за порушення заходів щодо запобігання поширенню інфекційних хвороб, є вимогою часу та сучасних обставин, у яких опинилась держава, зокрема через поширення пандемії гострого респіраторного захворювання COVID-19. Віднесення даної інфекційної хвороби до особливо небезпечних інфекційних хвороб сприяло внесенню відповідних змін до чинного законодавства в частині адміністративної та кримінальної відповідальності за правопорушення, які порушують порядок заходів щодо запобігання інфекційним хворобам.

Неоднозначність судової практики із застосування юридичної відповідальності, поспішність та нечіткість ухвалення урядом змісту ключової постанови про запроваджений карантин та відповідні заходи запобігання поширенню інфекційних хвороб свідчать про те, що механізм притягнення до передбаченої нині юридичної відповідальності потребує подальшого вдосконалення з урахуванням вимог сьогодення.

\section{Jimepamypa}

1. Про захист населення від інфекційних хвороб : Закон України від 6 квітня 2000 р. № 1645-III. URL: https://zakon.rada.gov.ua/laws/show/1645-14.

2. Про внесення зміни до Переліку особливо небезпечних, небезпечних інфекційних та паразитарних хвороб людини і носійства збудників цих хвороб, затвердженого наказом Міністерства охорони здоров’я України від 19 липня 1995 р. № 133 : наказ Міністерства охорони здоров’я України від 25 лютого 2020 р. № 521. URL: https://moz.gov.ua/article/ministry-mandates/nakaz-moz-ukrainivid-25022020--521-pro-vnesennja-zmini-do-pereliku-osoblivo-nebezpechnih-nebezpechnih-infekcijnih-taparazitarnih-hvorob-ljudini-i-nosijstva-zbudnikiv-cih-hvorob.

3. Про запобігання поширенню на території України гострої респіраторної хвороби COVID-19, спричиненої коронавірусом SARS-CoV-2 : постанова Кабінету Міністрів України від 11 березня 2020 р. № 211. URL: https://zakon.rada.gov.ua/laws/show/211-2020-\% D0\% BF\#Text. 
4. Про внесення змін до деяких законодавчих актів України, спрямованих на запобігання виникненню і поширенню коронавірусної хвороби (COVID-19) : Закон України від 17 березня 2020 р. № 530-IX. URL: https://zakon.rada.gov.ua/laws/show/530-20\#Text.

5. Кодекс України про адміністративні правопорушення від 7 грудня 1984 р. № 8073-X. URL: https://zakon.rada.gov.ua/laws/show/80731-10\#n216.

6. Основи законодавства України про охорону здоров'я : Закон України від 19 листопада 1992 р. № 2801-XII. URL: https://zakon.rada.gov.ua/laws/show/2801-12/ed19921119.

7. Про забезпечення санітарного та епідемічного благополуччя населення : Закон України від 24 лютого 1994 р. № 4004-XII. URL: https://zakon.rada.gov.ua/laws/show/4004-12.

8. Золотарьова М. Адміністративна відповідальність бізнесу за порушення карантинних норм. Поради адвоката. 7 квітня 2020 p. URL: https://ov-partners.com/administratyvna-vidpovidalnistbiznesu-za-porushennya-karantynnyh-norm-porady-advokata/.

9. Постанова Дніпровського районного суду м. Києва від 16 квітня 2020 р. у справі № 755/5547/20. URL: http://reyestr.court.gov.ua/Review/88797755.

10. Постанова Сарненського районного суду Рівненської області від 10 квітня 2020 р. у справі № 572/873/20. URL: http://www.reyestr.court.gov.ua/Review/89069586.

11. Постанова Тернівського міського суду Дніпропетровської області від 14 квітня 2020 р. у справі № 194/406/20. URL: http://www.reyestr.court.gov.ua/Review/88787368.

12. Постанова Бориспільського міськрайонного суду Київської області від 19 березня 2020 р. у справі № 359/2374/20. URL: http://reyestr.court.gov.ua/Review/88408690.

13. Постанова Семенівського районного суду Чернігівської області від 9 квітня 2020 р. у справі № 744/399/20. URL: http://www.reyestr.court.gov.ua/Review/88690337.

14. Кримінальний кодекс України : Закон від 5 квітня 2001 p. № 2341-III. URL: https://zakon.rada.gov.ua/laws/show/2341-14\#Text.

15. Вдовичен О. Ступінь та види відповідальності у зв'язку з карантином. 19 березня 2020 p. URL: https://ov-partners.com/stupin-ta-vydy-vidpovidalnosti-u-zvyazku-z-karantynom/.

16. Сербін А. Захист населення від інфекційних хвороб у період карантину. Місцеве самоврядування. 2020. № 4. URL: https://i.factor.ua/ukr/journals/ms/2020/april/issue-4/article-108052.html.

\section{Анотація}

Богдан Б. В. Юридична відповідальність за порушення заходів щодо запобігання інфекційним хворобам. - Стаття.

Наукова стаття присвячена аналізу змін, внесених до інституту юридичної відповідальності за порушення заходів, спрямованих на запобігання поширенню інфекційних хвороб. Зокрема, досліджено посилення адміністративної та кримінальної відповідальності фізичних осіб і посадових осіб у разі порушення заходів запобігання інфекційним хворобам. Наведено та проаналізовано приклади судової практики щодо застосування адміністративної відповідальності за порушення правил щодо карантину людей.

На підставі аналізу чинних нормативно-правових актів, якими врегульовано відносини в досліджуваній сфері, автором акцентовано увагу на тому, що карантин і обмежувальні протиепідемічні заходи являють собою заходи, які спрямовані передусім на запобігання поширенню інфекційних хвороб. Різниця полягає лише в тому, що обмежувальні протиепідемічні заходи застосовуються 3 метою запобігання поширенню інфекційних хвороб, а карантин - з метою запобігання особливо небезпечним інфекційним хворобам.

Зазначено, що під час протидії інфекційним хворобам може діяти низка обмежень, що узагальнено зводились до таких: заборонено відвідування закладів здобувачам освіти, проведення спортивно-масових заходів, регулярних перевезень пасажирів автомобільним і залізничним транспортом; припинено проведення планових заходів із госпіталізації, припинено проведення планових операцій; заборонено перебування у громадських місцях без одягнутих засобів індивідуального захисту - захисної маски або респіратора, низка інших.

Ілюстрацією притягнення до адміністративної відповідальності за порушення правил карантину людей є значна кількість судових рішень, які винесені протягом установленого урядом карантину на території України. Проте судова практика притягнення адміністративної відповідальності за вказане адміністративне правопорушення має неоднозначний характер: значна кількість судових справ передбачає повернення справи про адміністративне правопорушення до Управління патрульної поліції для належного оформлення. 
Аналіз наведених прикладів судової практики свідчить про відсутність єдиної правової позиції судів під час вирішення адміністративних справ за нововведеною статтею 44 Кодексу України про адміністративні правопорушення.

Ключові слова: відповідальність, порушення заходів, запобігання інфекційним хворобам, адміністративна відповідальність, штраф.

\section{Summary}

Bogdan B. $V$. Legal liability for violation of measures to prevent infectious diseases. - Article.

The scientific article is devoted to the analysis of the changes brought to the institute of legal responsibility for violation of the measures directed on prevention of distribution of infectious diseases. In particular, the strengthening of administrative and criminal liability of individuals and officials in violation of measures to prevent infectious diseases has been studied. Examples of court practice on the application of administrative liability for violating the rules on quarantine of people are given and analyzed.

Based on the analysis of current regulations governing the relationship in the study area, the author emphasizes that both quarantine and restrictive anti-epidemic measures are measures aimed primarily at preventing the spread of infectious diseases. The only difference is that restrictive anti-epidemic measures are used to spread infectious diseases, and quarantine is used to prevent particularly dangerous infectious diseases.

It is noted that during the fight against infectious diseases there may be a number of restrictions, which were generally reduced to the following: it is forbidden to visit educational institutions, holding sports events, regular transportation of passengers by road and rail; planned hospitalization measures were stopped, planned operations were stopped; it is forbidden to stay in public places without wearing personal protective equipment - a protective mask or respirator, and a number of others.

An illustration of the prosecution for violating the rules on quarantine of people is the significant number of court decisions issued during the quarantine established by the government in Ukraine. However, the case law in bringing administrative liability for this administrative offense is ambiguous: a significant number of court cases involve returning the case of an administrative offense to the Patrol Police Department for proper registration.

The analysis of the given examples of judicial practice testifies to the absence of a single legal position of courts in resolving administrative cases under the newly introduced Article 44 Code of Ukraine on Administrative Offenses.

Key words: responsibility, violation of measures, prevention of infectious diseases, administrative responsibility, fine. 